\title{
The Analysis of the Effect of Interest Rate, Inflation, and Gold Prices on the Deposit Amount at PT. Bank Mandiri
}

\author{
Retta Melida Pasaribu ${ }^{1, *}$, Fitrawaty ${ }^{1}$, Muhammad Yusuf ${ }^{1}$ \\ ${ }^{1}$ Department of Economics Post Graduate, Universitas Negeri Medan \\ *Corresponding Author. Email: rettapasaribu92@ gmail.com
}

\begin{abstract}
The aims of the research are to analyze (1) the effect of interest rates on the amount of deposits at PT. Bank Mandiri KCP Ahmad Yani Medan period 2016-2019, (2) the effect of inflation on the amount of deposits at PT. Bank Mandiri on the branch office of Ahmad Yani in Medan period 2016-2019, (3) the effect of gold prices on the amount of deposits on the branch office of Ahmad Yani period 2016-2019. The type of research is Exploitation Research, namely research that aims to explain the actual condition and characteristics of a research object based on the information obtained and the research used the secondary data. The research result shows that the interest rate has no effect significantly on the amount of deposits on the branch office of Ahmad Yani. This is indicated by the insignificant probability value of the effect of interest rates on total deposits $0.3440>0.05$. Inflation has no effect significantly on the amount of deposits on the branch office of Ahmad Yani. This is indicated by the insignificant probability value of the effect of inflation on the number of deposits $0.2650>0.05$. Gold Price has a negative and significant effect on the amount of deposits of on the branch office of Ahmad Yani. This is indicated by the probability value of the effect of the gold price on the significant amount of deposits with a negative regression coefficient $0.0000<0.05$ and a negative regression coefficient of 0.001407. The fall in the gold prices can increase the amount of public deposits on the branch office of Ahmad Yani. The amount of contribution given by the variable interest rate, inflation and gold price was $73,23 \%$ while the remaining $26,77 \%$ variance in the amount of public deposits was influenced by other factors apart from interest rates, inflation and gold prices.
\end{abstract}

Keywords: Interest Rate, Inflation, Gold Price, Deposit

\section{INTRODUCTION}

The banking sector is one of the most influential factors on the global economy in general and a country in particular. This is evidenced by the global economic crisis, caused by the international banking crisis that occurred in New York, known as the term "Panic Of 1907". In Indonesia, there has been a monetary crisis, this event occurred in 1998 which caused the Indonesian economy to decline.

Inflation is defined as a condition where there is a sharp (absolute) increase in prices that lasts continuously for a long period of time followed by a decline in the real (intrinsic) value of a country's currency.

The main cause and the only thing that allows this symptom to appear is the result of excess money in circulation as a result of the increase in the amount of money in society [32]. Inflation is an economic turmoil that is very interesting to pay attention to because whenever there is social, political or economic turmoil at home or abroad, the public always associates it with the problem of inflation. Inflation is also biased to indicate the vulnerability of a country's economy so that this greatly affects investment confidence, especially foreign capital on the prospects for income that will be obtained in that country [38].

In 2017, the interest rate was the highest rate at $7.53 \%$ and in 2019 the interest rate was in the low category, namely5.88\%. With an economy rotating too fast and prices rising rapidly (inflation), the central bank will put the brakes on increasing interest rates. An increase in interest rates will dampen people's desire to shop or expand their business because the cost of borrowing money, which is indicated by credit interest rates, becomes more expensive. Thus, it is better if the decrease in interest rates will reduce the intention to borrow money 
from the bank and inflation will increase because many people will shop or expand their business.

The price of gold always fluctuates in the short term. In the long run, however, these fluctuations lead to an increase in the value of gold. As can be seen from the Gold Price Movement (IDR) Chart for the last 20 years sourced from www.goldprice.org, in the long run the gold price has led to an increase in value. For this reason, investors must pay attention to the factors that affect the price of gold in order to make a profit.

\section{LITERATURE REVIEW}

\subsection{The Loanable Fund Theory}

According to [16], Loanable Fund is a fund that can be allocated for providing credit or for purchasing securities with the aim of earning income. This theory states that the interest rate is not determined by the demand and supply of savings third-party funds

According to Bank Indonesia Regulation No. 10/19 / PBI / 2008 explains, "bank third party funds, hereinafter referred to as TPF, are bank liabilities to residents and non-residents in rupiah and foreign currencies". The purchase of funds from the public is carried out by banks through various strategies so that people are interested and willing to invest their funds.

Through bank financial institutions [3]. According to [5], there are 3 types of direct sources of funds from the community, namely a savings account (saving deposit), time deposit account, and demand deposit account. In addition, there are also other sources of funds that are indirect in nature or in the form of deposition of bank funds obtained through the provision of bank services (fee-based income). According to Ismail [22], third party funds are usually known as public funds, which are funds collected by banks that come from the community in abroad sense, including individual communities, as well as business entities.

\subsection{Interest Rate}

The interest rate is the price of the use of investment funds (loanable funds). The interest rate is an indicator in determining whether someone will invest or save [11].

\subsection{Inflation}

According to [12], inflation is the tendency of general and continuous price increases. There are three components that must be fulfilled in order to say that inflation has occurred, including:

\section{a. Price increases}

The price of a commodity is said to increase if it becomes higher than the price of the previous period. bank finance [33]. According to [5], there are 3 types of direct sources of funds from the community, namely a savings account (saving deposit), time deposit account, and demand deposit account. In addition, there are also other sources of funds that are indirect in nature or in the form of deposition of bank funds obtained through the provision of bank services (fee-based income). According to Ismail [22], third party funds are usually known as public funds, which are funds collected by banks that come from the community in a broad sense, including individual communities, as well as business entities.

\section{b. General}

An increase in the price of a commodity cannot be said to be inflation if the increase does not cause prices in general to rise.

\section{c. Going on continuously}

A general price increase will also not lead to inflation, if it occurs momentarily, therefore inflation calculations are carried out within the minimum monthly time frame.

\subsection{Gold Prices}

Since 1968, the gold price that has been used as a worldwide benchmark is the price of gold based on the London gold market standard. This system is called the London Gold Fixing. London Gold Fixing is a procedure where by the gold price is determined twice a day every working day on the London market by five members of the London Gold Fixing Ltd. Market. According to www.goldfixing.com, the five members are: 1) Bank of Nova Scottia 2) Barclays Capital 3) Deutsche Bank 4) HSBC 5) Societe Generale.

\section{METHOD}

\subsection{Types and Sources of Data}

This type of research is exploitation research, which is research that aims to explain the actual condition and characteristics of a research object based on the information obtained. The source of the data used in this research is quantitative data, namely data that is measured in a numerical scale (numbers). This study uses secondary data, namely data that has been collected by data collection agencies and published to the data user public.

\subsection{Population and Sample}

Population is a generalization area consisting of objects or subjects that have certain qualities and characteristics that are determined by researchers to study and then draw conclusions [44]. The population in this study is monthly time series data for 3 years, starting from January 2017 to December 2019.

\subsection{Descriptive Statistics}

In this study, descriptive analysis was used to describe interest rates, inflation, gold prices and the amount of public deposits on the branch office of Ahmad Yani. Descriptive analysis was carried out by looking at the maximum, minimum, mean and standard deviation values. 


\section{RESULT AND DISCUSSION}

This chapter describes in detail an overview of the related research locations, describing the treatment of data in tables and statements in accordance with the analytical method used. As well as disclosing the interpretations based on the results of the presentation and analysis of data based on the theories relevant to the research.

Table 1. Descriptive Statistics

\begin{tabular}{|l|c|c|c|c|}
\hline & Deposito & $\begin{array}{c}\text { Interest } \\
\text { Rate }\end{array}$ & Inflation & Gold Price \\
\hline Mean & 631038.2 & 5.286458 & 0.256667 & 569.8333 \\
\hline Median & 626828.0 & 5.000000 & 0.220000 & 561.5000 \\
\hline Maximum & 727979.0 & 7.250000 & 0.970000 & 699.0000 \\
\hline Minimum & 545706.0 & 4.250000 & -0.450000 & 498.0000 \\
\hline Std. Dev. & 51579.70 & 0.853637 & 0.289073 & 49.92221 \\
\hline Observations & 48 & 48 & 48 & 48 \\
\hline
\end{tabular}

Based on the results of the analysis in Table 1, the following results were obtained:

- The variable of the amount of deposits in this study shows the amount of public savings at Bank Mandiri. The results of the analysis in Table 1 show that the number of public deposits at Bank Mandiri has the lowest value of 545706 billion rupiah and the highest value is 727979 billion rupiah, the amount of public deposits during the period 2016 - 2019 has an average of 631038.2 billion rupiah with standard deviation of 51579.7 .

- The interest rate variable in this study shows the amount of the BI Bank interest rate during 2016 2019. This interest rate is calculated monthly. The results of the analysis in Table 1 show that during the 2016-2019 period, the BI interest rate had the lowest value of 4.25 percent and the highest was 7.25 percent with an average of 5.323 percent and a standard deviation of 0.846 . Inflation. Inflation is a process in which prices are continuously increasing due to various factors, among others, increased public consumption, the existence of a smooth distribution of goods and various other factors causing inflation. The results of the analysis in Table 1 show that inflation during the $2016-2019$ period had the lowest value - 0.45 percent and the highest was 0.97 percent with an average of 0.257 percent and a standard error of 0.289 .

- The gold price variable in this study shows the monthly gold price during the period 2016 - 2019. The analysis results in Table 1 show that the gold price during this period ranged from Rp. 498,000, up to Rp. 699,000, - per gram with an average of Rp. 569,833 , - with a standard deviation of 49,922 .

Based on Figure 1 above, a probability value is obtained of $0.459>0.05$, which indicates that the regression residual data is normally distributed. This means that the regression model has met the normality assumption.

Based on the results of the multicollinearity test in Table 2 above, there are no variables that have a value higher than 0.732275 for the function of the amount of deposits, it is concluded that there is no multicollinearity in the regression model.

Figure 1. Normality Test

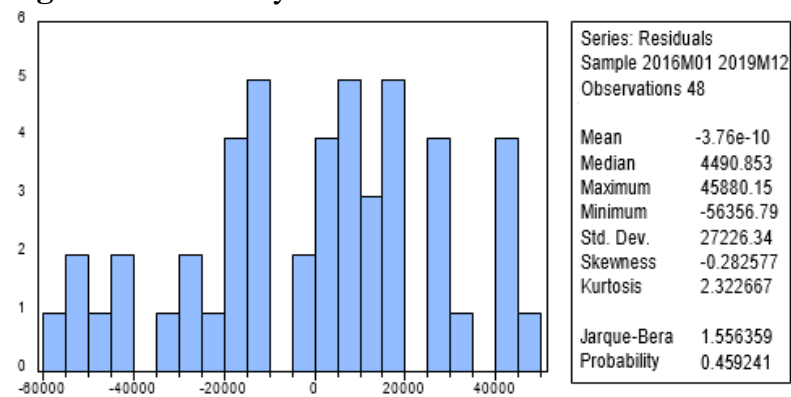

Table 2. Multicollinearity Test

\begin{tabular}{|c|c|c|c|}
\hline VAR & RATE & INF & PG \\
\hline RATE & 1 & 0.009197 & C \\
\hline INF & -0.009197 & 1 & -0.144658 \\
\hline PG & -0.144658 & -0.144658 & 1 \\
\hline
\end{tabular}

Table 3. Heteroscedasticity Test

\begin{tabular}{|c|c|c|c|}
\hline R-squared & 0.732275 & $\begin{array}{c}\text { Mean dependent } \\
\text { var }\end{array}$ & 13.35184 \\
\hline Adjusted R-squared & 0.714021 & S.D.Dependent var & 0.081911 \\
\hline
\end{tabular}

Based on the results of the heteroscedasticity test in table 3 above, it can be seen that after testing, the results of R2 are usually relatively equal to 0.732275 and $\mathrm{R} 2$ white is equal to 0.732275 . So, there is no heteroscedasticity problem.

Based on the results of the autocorrelation test in Table 4, the probability value obtained is 0.0000 . Because the probability value obtained is $<0.05$, it is concluded that there is autocorrelation in the regression model.

\subsection{Partial Influence}

1) The interest rate has no effect significantly on the amount of deposits of PT. Bank Mandiri KCP Ahmad Yani Medan. This is indicated by the insignificant probability value of the effect of interest rates on total deposits, namely with aprobabilityvalue of $0.3440>0.05$. This shows that the high and low BI interest rates (BI rate) do not effect significantly the amount of public deposits at Bank Mandiri KCP Ahmad Yani Medan.

2) Inflation has no effect significantly on the amount of deposits of PT. Bank Mandiri KCP Ahmad Yani Medan. This is indicated by the insignificant probability value of the effect of inflation on the 
Table 4. Autocorrelation Test

Breusch-Godfrey Serial Correlation LM Test:

$\begin{array}{llll}\text { F.Statistic } & 42.49706 & \text { Prob.F(2,42) } & 0.0000\end{array}$

Obs*R-squared 32.12525 Prob. Chi-Square(2) 0.0000

number of deposits, namely the probability value of $0.2650>0.05$. This shows that high and low inflation does not affect significantly the amount of public deposits at Bank Mandiri KCP Ahmad Yani Medan.

3) Gold Price has a negative and significant effect on the total deposits of PT. Bank Mandiri KCP Ahmad Yani Medan. This is indicated by the probability value of the effect of the gold price on the significant amount of deposits with a negative regression coefficient, namely a probability value of $0.0000<0.05$ and a negative regression coefficient of -0.001407 . This shows that the higher the price of gold, the decreasing the amount of public deposits at Bank Mandiri KCP Ahmad Yani Medan. The fall in the price of gold can increase the amount of public deposits at Bank Mandiri KCP Ahmad Yani Medan.

4) The amount of contribution given by the variable interest rate, inflation and gold price was $73.27 \%$ while the remaining $26.73 \%$ variance in the amount of public deposits was influenced by other factors apart from interest rates, inflation and gold prices

\section{CONCLUSION AND SUGGESTION}

\subsection{Conclusion}

The conclusions obtained from the results of this study are as follows:

1) The interest rate has no effect significantly on the amount of deposits of PT. Bank Mandiri KCP Ahmad Yani Medan. This is indicated by the insignificant probability value of the effect of interest rates on total deposits, namely with a probability value of $0.3440>$ 0.05. This shows that the high and low BI interest rates (BI rate) do not effect significantly the amount of public deposits at Bank Mandiri KCP Ahmad Yani Medan.

2) Inflation has no effect significantly on the amount of deposits of PT. Bank Mandiri KCP Ahmad Yani Medan. This is indicated by the insignificant probability value of the effect of inflation on the number of deposits, namely the probability value of $0.2650>0.05$. This shows that high and low inflation does not affect the amount of public deposits at Bank Mandiri KCP Ahmad Yani Medan.

3) Gold Price has a negative and significant effect on the total deposits of Pt. Bank Mandiri KCP Ahmad Yani Medan. This is indicated by the probability value of the effect of the gold price on the significant amount of deposits with a negative regression coefficient, namely a probability value of $0.0000<0.05$ and a negative regression coefficient of -0.001407 . This shows that the higher the price of gold, the decreasing the amount of public deposits at Bank Mandiri KCP Ahmad Yani Medan. The fall in the price of gold can increase the amount of public deposits at Bank Mandiri KCP Ahmad Yani Medan.

\subsection{Suggestion}

Future research is expected to add research samples with different types of companies or by taking different research periods.

For investors, when investing in a bank in the form of deposits it can add to the consideration of the exchange rate condition factor. Because the increase in the value of the exchange rate will increase public interest and participation in investing in banks.

\section{REFERENCES}

[1] Dimarwan, A Karim. Bank Islam: Analisis Fiqih dan Keuangan Edisi 3. Jakarta: PT. Raja Grafindo Persada.2008.

[2] Agus Harjito dan Martono.Manajemen Keuangan. Yogyakarta: Ekonisia, 2010.

[3] Anonimous,Kajian Stabilitas Keuangan no 19, September 2012, Bank Indonesia, Jakarta,2012.

[4] Ariefianto, Moch Doddy, Ekonometrika: Esensi dan Aplikasi Menggunakan Eviews Jakarta: Erlangga, 2012.

[5] Arthesa, et al. Bank dan Lembaga Keuangan Bukan Bank. Jakarta: Indeks, 2006.

[6] Bank Sentral Republik Indonesia, Laporan Moneter, BI-Rate, www.bi.go.id diakses tanggal 23 Nopember 2020.

[7] Bank Sentral Republik Indonesia, Pengenalan Inflasi, www.bi.go.id diakses tanggal 20 Nopember 2020 .

[8] Bank Sentral Republik Indonesia, Pidato Dewan Gubernur, www.bi.go.id diakses tanggal 17 Februari 2019.

[9] Bank Sentral Republik Indonesia, Publikasi Bank Indonesia, www.bi.go.id diakses tanggal 20 Nopember 2020.

[10] Barnadib, Iman. Dasar-dasar Kependidikan: Memahami Makna dan Prespektif Beberapa Teori Pendidikan. Bogor: Ghalia Indonesia, 1996.

[11] Boediono. Ekonomi Moneter, Seri Sinopsis Pengantar Ilmu Ekonom No.2. Yogyakarta: BPFE. 1994.

[12] Boediono, Ekonomi Makro, Edisi Empat, Jilid 2, Yogyakarta: BPFE, 2001.

[13] Darmadi, Hamid. Metode Penelitian Pendidikan dan Sosial, Bandung: Alfabeta, 2013. 
[14] Dermawan. Wibisono, Riset Bisnis: Panduan Bagi Praktisi dan Akademis,Jakarta: Gramedia Pustaka Utama, 2003.

[15] Enders, W. Applied Econometric Time Series, (New York: John Wiley \& Sons Inc, 2004.

[16] Firdaus, H.Rachmat dan Maya Ariyanti. Manajemen Perkreditan Bank Umum. Bandung: Alfabeta, 2011

[17] Ghofur Anshori, Abdul. Perbankan Syariah Di Indonesia, Yogyakarta: Gadjah Mada University Press, 2007.

[18] Halim, Abdul. Analisis Investasi. Edisi Pertama. Jakarta: SalembaEmpat,2003

[19] Hasibuan, Malaya S.P. Dasar-Dasar Perbankan, Jakarta: Bumi Aksara, 2009. Huda, Miftahul. Model-Model Pengajaran dan Pembelajaran. Yogyakarta: Pustaka Pelajar. 2013

[20] Indriantoro, dkk. Metodologi Penelitian dan Bisnis. Yogyakarta: BPFE. 1999.

[21] Irham Fahmi.Pengantar Perbankan "teori dan aplikasi”. Bandung: Alfabeta,2014.

[22] Ismail. Perbankan Syariah. Jakarta: Kencana Prenada Media Group. 2013

[23] Jasfar Farida. "Manajemen Jasa", Cetakan Pertama, Ciawi-Bogor: Ghalia Indonesia, 2005.

[24] Juliansyah, Noor. Metode Penelitian, Jakarta: Kencana Prenada MediaGroup,2012.

[25] Junaiddin Zakaria, Pengantar Teori Ekonomi Makro, Jakarta: GaungPersada, 2009.

[26] Karl dan Fair. Pembayaran Bunga Tahunan Dari Suatu Pinjaman, Dalam Bentuk Persentase Dari Pinjaman yang Diperoleh, Yogjakarta: YKPN.

[27] Kasmir, Dasar-dasar Perbankan, Jakarta: Rajawali Pers, 2012.

[28] Keith, Pilbeam. International Finance3rd Edition. New York: Palgrave MacMillan, 2006.

[29] Khalwaty, Tajul. Inflasi dan Solusinya. Jakarta: PT.Gramedia Pustaka Utama. 2000.

[30] Kuncoro, Mudrajat. Metode Riset: Untuk Bisnis dan Ekonomi, Jakarta: Erlangga, 2002.

[31] Latumaerissa Julius, Bank dan Lembaga Keuangan Lainnya, Cetakan Pertama, Jakarta: Salemba Empat, 2011.

[32] Marieskha, Poppy. Analisis Pengaruh PDRB, Suku Bunga dan Tingkat Inflasi Terhadap Simpanan Masyarakat Pada Bank-Bank Umum di Sumatera Utara. Skripsi. Universitas Sumatera Utara. 2009.

[33] Martono, Nanang. Metode Penelitian: Analisis Isi dan Analisis Data Sekunder. Jakarta: Rajawali Press. 2010.
[34] Nopirin. Ekonomi Moneter 2. Yogyakarta: BPFE. 1992.

[35] Nugroho, Agung. Strategi Jitu Memilih Metode Statistik Penelitian dengan SPSS. Yogyakarta: Andi Yogyakarta. 2005.

[36] Nugroho, Yohanes. 2010. Analisis Faktor-faktor Yang Mempengaruhi Tingkat Suku Bunga Deposito Pada Bank Umum di Indonesia Tahun 2006-2008. Skripsi. Universitas Diponegoro Semarang.

[37] Rivai, Veithzal., et.al. (2013). Commercial Bank Management (manajemen Perbankan dan Teori ke Praktik). Jakarta: PT. Rajagrafindo Persada.

[38] Rodoni, Ahmad dan Abdul Hamid. Lembaga Keuangan Syariah. Jakarta: Zikrul. 2008.

[39] Sania, Zulcha Mintachus. (2016). Pengaruh DPK, NPL dan CAR terhadap Jumlah Penyaluran Kredit Perbankan Persero. Jurnal Ilmu Dan Riset Manajemen, 5(1), 1-15. ISSN: 2461-0593.

[40] Santosa, Budi. Data Mining Teknik Pemanfaatan Data Untuk Keperluan Bisnis. Yogyakarta: Graha Ilmu. 2007.

[41] Sari, Greydi Normala. (2012). Faktor-faktor yang Mempengaruhi Penyaluran Kredit Bank Umum di Indonesia (Periode 2008.1 - 2012.2). Jurnal EMBA, 1(3), 931-941.

[42] Sartika, Rina Utami. (2014). Pengaruh FaktorFaktor Internal Bank Terhadap Pertumbuhan Penyaluran Kredit Perbankan (Studi pada Bank Umum Konvensional di Indonesia). Universitas Pendidikan Indonesia.

[43] Sinungan, Muchdarsyah. (2010). Manajemen Dana Bank. Jakarta: Bumi Aksara.

[44] Sugiyono. Statistika Untuk Penelitian. Bandung: Alfabeta. 2010

[45] Sugiyono. (2013). Metode Penelitian Bisnis. Bandung: Alfabeta.

[46] Suharyadi dan Purwanto,S.K. Statistika Untuk Ekonomi dan Keuangan Modern Jilid 1. Jakarta: Salemba Empat. 2003.

[47] Sukirno, Sadono. Ekonomi Pembangunan. Jakarta: Kencana. 2006.

[48] www.bps.go.id www.goldprice.org

[49] Witjaksono, Ardian Agung. Analisis Pengaruh Tingkat Suku Bunga SBI, Harga Minyak Dunia, Harga EmasDunia, Kurs Rupiah, Indeks Nikkei 225, dan Indeks Dow Jones terhadap IHSG (Studi Kasus Pada IHSG di BEI selama Periode 2000-2009). Tesis. Program Pascasarjana Universitas Diponegoro. 2010.

[50] https://www.bps.go.id/linkTableDinamis/view /id/1061

https://www.bps.go.id/statictable/2009/06/15/ 
[51] 907/indeks-harga-konsumen-dan-inflasi-bulananindonesia-2006-2020.html

[52] https://id.investing.com/commodities/goldhistorical-data

[53] https://www.bi.go.id/id/statistik/ekonomikeuangan/seki/Default.aspx

[54] Indrayenti. Susanti. (2015). Pengaruh Tingkat Suku Bunga Simpanan Terhadap Jumlah Deposito Pada Pt. Bank Rakyat Indonesia (Persero) Tbk. Cabang Liwa. Jurnal Akuntansi \& Keuangan, 151(1), 1017.

[55] Sholikha, A. F. (2018). Pengaruh Tingkat Suku Bunga, Tingkat Bagi Hasil, Likuiditas, Inflasi, Ukuran Bank, Dan Pertumbuhan Produk Domestik Bruto Terhadap Deposito Mudharabah Bank Umum Syariah di Indonesia. El-Jizya: Jurnal Ekonomi Islam, 6(1), 1-22. https://Doi.Org/10.24090/Ej.V6i1.2045 